\section{Late-onset neonatal sepsis in preterm infants with birth weight under $1.500 \mathrm{~g}$}

Sepse neonatal tardia em recém-nascidos pré-termo com peso ao nascer inferior a $1.500 \mathrm{~g}$

Sepsis neonatal tardía en recién nacidos prematuros con peso al nacer menor que $1.500 \mathrm{~g}$

\author{
Stella Marys Rigatti Silva ${ }^{a}$ \\ Giordana de Cássia Pinheiro da Motta ${ }^{b}$ \\ Cristiane Raupp Nunes ${ }^{b}$ \\ Juliana Machado Schardosim ${ }^{c}$ \\ Maria Luzia Chollopetz da Cunha ${ }^{d}$
}

\section{ABSTRACT}

Objective: the research objective was to characterize preterm infants with birth weight under $1500 \mathrm{~g}$, and to identify the incidence of late-onset neonatal sepsis among this population.

Methods: a prospective cohort study with a sample of 30 preterm newborns that weighed under $1500 \mathrm{~g}$ and were hospitalized in the NICU of the university hospital. Data were collected from January to December 2013 using a structured instrument.

Results: of the 30 neonates included in the study, 14 developed late-onset neonatal sepsis with a prevalence of coagulase-negative staphylococci.

Conclusions: the incidence of late-onset neonatal sepsis indicates a vulnerability in preterm infants due to immunological immaturity. These results reveal that knowledge of the profile of newborn infants admitted to the NICU and the risk factors to which they are exposed are central to the planning of nursing care for these patients. Future studies should address strategies for preventing nosocomial infection.

Keywords: Infant, newborn. Infant, premature. Sepsis. Intensive care units, neonatal. Neonatal nursing.

\section{RESUMO}

Objetivo: 0 objetivo da pesquisa foi caracterizar os recém-nascidos pré-termo nascidos com peso inferior a 1.500g e identificar a incidência de sepse neonatal tardia.

Métodos: realizou-se um estudo de coorte prospectivo, cuja amostra foi composta por 30 recém-nascidos pré-termo com peso inferior a 1.500g, internados em UTI Neonatal de um hospital universitário. A coleta de dados ocorreu de janeiro a dezembro de 2013 por meio de instrumento estruturado.

Resultados: foram incluídos 30 neonatos, dos quais 14 desenvolveram sepse neonatal tardia, prevalecendo o Staphylococcus Coagulase negativo.

Conclusões: a incidência de sepse neonatal tardia indica a vulnerabilidade desses pré-termos, devido à imaturidade imunológica dessa população. Assim, o conhecimento do perfil dos RN internados na UTIN e os fatores de risco a que estão expostos são fundamentais para o planejamento dos cuidados de enfermagem desses pacientes. Futuros estudos são necessários para desenvolver estratégias para a prevenção da infecção nosocomial.

Palavras-chave: Recém-nascido. Prematuro. Sepse. Unidades de terapia intensiva neonatal. Enfermagem neonatal.

\section{RESUMEN}

Objetivo: el objetivo de la investigación fue caracterizar los recién nacidos prematuros con peso al nacer inferior a 1.500g e identificar la incidencia de sepsis neonatal tardía en ellos.

Métodos: se realizó un estudio de cohorte prospectivo, cuya muestra fue compuesta por 30 recién nacidos prematuros con peso inferior a 1.500g, hospitalizados en la UCI Neonatal de un hospital universitario. La recolección de datos se llevó a cabo a partir de enero a diciembre 2013 utilizando un instrumento estructurado.

Resultados: entre los 30 prematuros incluidos en el estudio, 14 desarrollaran sepsis neonatal tardía, siendo predominante el Staphylococcus Coagulase negativo.

Conclusiones: I incidencia de sepsis neonatal tardía muestra la vulnerabilidad de los prematuros, debido a la inmadurez inmunológica de esa población. Por lo tanto, el perfil de RN del conocimiento admitido en la UCIN y los factores de riesgo a que están expuestos son fundamentales para la planificación de los cuidados de enfermería a los pacientes. Se necesitan más estudios para desarrollar estrategias para la prevención de la infección hospitalaria.

Palabras clave: Recién nacido. Prematuro. Sepsis. Unidades de cuidado intensivo neonatal. Enfermería neonatal.
D0l: http://dx.doi.org/10.1590/19831447.2015.04.50892

a Santa Casa de Misericórdia de Porto Alegre, Centro de Neonatologia do Hospital Santa Clara. Porto Alegre, Rio Grande do Sul, Brasil.

${ }^{b}$ Hospital de Clínicas de Porto Alegre (HCPA). Porto Alegre, Rio Grande do Sul, Brasil.

c Universidade de Brasília (UnB). Faculdade de Ceilândia. Brasília, Distrito Federal, Brasil.

¿ Universidade Federal do Rio Grande do Sul (UFRGS), Escola de Enfermagem, Programa de Pós-Graduação em Enfermagem, Curso de Graduação em Enfermagem. Porto Alegre, Rio Grande do Sul, Brasil. 


\section{口INTRODUCTION}

Premature births are associated to the high risk of neonatal mortality ${ }^{(1)}$. In Brazil the preterm birth rate is $9.2 \%{ }^{(2)}$. According to the World Health Organization, around 15 million premature infants are born every year all over the world. However, more than a million of these babies die shortly after birth, and many suffer from some type of lifelong physical, neurological or educational impairment, which generates high costs for their families and for society ${ }^{(2)}$.

In Brazil, an estimated $60 \%$ of infant mortality occurs in the neonatal period, and neonatal sepsis is one of the main causes of these deaths according to data from the mortality information system ${ }^{(3)}$.

Preterm birth is the major risk factor for neonatal sepsis. The risk of infection among preterm infants is 11 times greater than among full-term newborns ${ }^{(4)}$. Preterm newborns have immature skin and mucous barriers and an underdeveloped defence mechanism against infection. They are also immunodeficient in the production of immunoglobulin, in the complement system (C3 and C5) and in their capacity of opsonization and phagocytosis ${ }^{(4)}$. The lower the birth weight, the greater the risk of developing neonatal sepsis. Gestational age influences the risk of neonatal sepsis in the same way ${ }^{(5)}$.

Sepsis is defined by isolating an organism by means of a blood culture on the newborn with clinical symptoms of infection. In most studies, the isolation of an organism using blood cultures is considered evidence of neonatal sepsis( ${ }^{(6)}$.

Neonatal sepsis is classified as early-onset and late-onset. In early-onset sepsis, the newborn shows symptoms in the first incomplete three days of life, that is, with less than 72 hours of age, and it is related to maternal risk factors. The bacteria found in the cultures are present in the birth canal. In late-onset sepsis, the symptoms occur from the fourth day of life, that is, with more than 72 hours of age. This form of sepsis is related to neonatal factors and generally affects newborns who are hospitalized in Neonatal Intensive Care Units (NICU), which means that it is acquired in the hospital environment ${ }^{(7)}$. Late-onset neonatal sepsis is strongly associated with the procedures and contamination present in the NICU. Preterm newborns are infected with microorganisms by indirect human contact with the contaminated environment. Consequently, horizontal transmission is a major factor in the development of late-onset neonatal sepsis and preventive interventions should be carried out in the NICU in order to minimize this exposure ${ }^{(3)}$.

The increased survival rates of preterm newborns elevates the rate of late-onset sepsis in the NICU. These newborns require long hospitalization periods and are submit- ted to several treatments and invasive procedures that put them at a higher risk of acquiring infection ${ }^{(7)}$.

Late-onset neonatal sepsis is more common in premature infants with a low birth weight. Studies conducted in the United States found that newborn babies weighing less than $1500 \mathrm{~g}$ developed one or more episodes of late-onset neonatal sepsis with positive blood cultures $^{(8)}$. If sepsis is not diagnosed in the initial stages, the newborn may rapidly evolve to septic shock, disseminated intravascular coagulation and death ${ }^{(9-10)}$. Neonatal sepsis with the consequent septic shock is a major cause of infant morbidity and mortality ${ }^{(10)}$. Preterm newborns who have had neonatal sepsis have a higher risk of late neurodevelopment, especially difficulties in learning, cognition, cerebral palsy and hearing and visual deficits at the corrected age of 2. Gram-positive microorganisms are associated with cognitive and motor delays in these newborns ${ }^{(10)}$. Although septic shock is a serious outcome that raises the rates of morbidity and mortality, some promising strategies have been evaluated to prevent its onset ${ }^{(11)}$.

Clinical studies suggest that the permanence of a central venous catheter, the use of mechanical ventilation, enteric feeding and skin sores are high-risk factors for late-onset neonatal sepsis, and that preventive strategies should be adopted in NICU to reduce colonization ${ }^{(12)}$.

Most studies with newborns with a birth weight of under $1500 \mathrm{~g}$ are from foreign literature. In Brazil, there is a shortage of studies published on the subject of newborns with extremely low and very low birth weight and a lack of research conducted by nurses, which stresses the importance of research with preterm infants who are highly susceptible to infection. Therefore, the guiding question of this study is: what are the characteristics of preterm infants weighing under $1500 \mathrm{~g}$ that develop late neonatal sepsis? The results of this study can contribute to the investigation of late-onset neonatal sepsis among premature babies. Unlike full-term newborns, this population has unique immunological characteristics due to immaturity and therefore require a specific study. Since nurses must provide more prolonged care, they must be aware of the susceptibility of these patients and pay extra attention to the risk factors. As team managers, nurses must plan care in order to minimize the risks and prevent infections in the NICU.

The aim of this paper is to characterize preterm infants with birth weight under $1500 \mathrm{~g}$, and to identify the incidence of late-onset neonatal sepsis among this population.

\section{GETHODS}

This is a prospective cohort study with a sample group consisting of preterm infants born weighing less than 
$1500 \mathrm{~g}$, from $1 / 1 / 2013$ to $12 / 31 / 2013$. The sample group included newborns of the Hospital de Clínicas de Porto Alegre (HCPA) weighing less than $1500 \mathrm{~g}$ and admitted in the NICU shortly after birth. The criteria for exclusion were preterm infants with a congenital malformation; infants of mothers who tested positive for human immunodeficiency virus; infants of mothers with any of the following infections: syphilis, toxoplasmosis, hepatitis, rubella, chickenpox during pregnancy; infants of mothers with a membrane rupture $\geq 18$ hours before labour, with fever $\geq 37.8^{\circ} \mathrm{C}$, with infection of the ovary or other bacterial infection that can be transmitted to the foetus; infants of mothers undergoing chemotherapy and preterm infants with suspected infection at the time of birth.

After authorization of the parents, data were collected using a standardized form and the electronic and paper medical records. This instrument contained demographic variables (sex, multiple birth and type of labour) and clinical variables of the preterm infants that participated in the study. The variables that were considered risk factors for late-onset neonatal sepsis were use and permanence of a central venous catheter, time and permanence of mechanical ventilation, NPO time (Nil Per Os; Latin for nothing by mouth), use and time of enteral and parenteral nutrition. This study observed the use of mechanical ventilation, use of endotracheal tube in pressure support ventilation or pressure controlled ventilation on the newborn. The use of a nasal prongs associated to continuous positive airway pressure (CPAP) was also investigated. The observed central venous catheter (CVC) included the use of the peripherally inserted central catheter (PICC), the umbilical arterial catheter (UAC) or the umbilical venous catheter (UVC). The definition of late-onset neonatal sepsis as based on the criteria found in literature ${ }^{(5)}$, according to the "gold standard" for a positive blood culture diagnosis obtained after 72 hours of age of the newborn.

Data collected in the instrument were entered into an Excel for Windows spreadsheet. Data were subjected to descriptive analysis with absolute number and percentage for the categorical variables and average, standard deviation, median and interquartile range for the quantitative variables, according to the distribution of these variables. Data were analysed using the PASW Statistics programme (Predictive Analytics Software) version 18.0.

The project was approved by the Comitê de Ética em Pesquisa com Seres Humanos of the Hospital de Clínicas de Porto Alegre, under protocol number 12-0361. The parents/persons responsible authorized the participation of the infants and signed an informed consent statement. The researchers signed a statement for the use of data from the patients' medical records. This study was extracted from a master's dissertation titled "Características dos recém-nascidos pré-termo com peso inferior a 1.500g e sepse neonatal"(13).

\section{RESULTS}

In 2013, 3938 infants were born in the HCPA. Of these infants, 75 were born weighing less than $1500 \mathrm{~g}$. Thirty three (33) newborns were excluded from the study. Of these 33, 15 were the infants of mothers with suspected infection at the moment of delivery, four died during the first hours of life, nine were the infants of mothers with ruptured membrane more than 18 hours prior to delivery, two infants had congenital syphilis, one newborn had a congenital malformation, one was the infant of a mother with HIV, and one infant had suspected sepsis at birth. One newborn passed away and tested positive for sepsis the first 72 hours after birth. There was no death in the sample during the period of hospitalization in the NICU. It was not possible to obtain the signature for the informed consent statement of eleven newborns. Therefore, the study comprised 30 preterm infants born from January to December 2013. Table 1 shows the clinical and demographic characteristics of the infants.

In relation to adaptation to extrauterine life, most of the newborns required neonatal resuscitation manoeuvres in the delivery room, and five (17\%) newborns required endotracheal intubation in the delivery room. As for the development of other diseases or complications, five newborns (17\%) had neonatal respiratory distress syndrome (NRDS), five suffered from bronchopulmonary dysplasia (17\%) and one infant suffered from necrotizing enterocolitis (3.3\%).

All ventilatory support was initiated in the first 24 hours of life. Most cases (96.6\%) required central venous catheter (CVC), with a higher prevalence of the PICC. The catheters were inserted on the first day of life of the newborn. The permanence and type of CVC are described below. In relation to total parenteral nutrition (TPN), 28 (93.3\%) newborns relied on this therapy, followed by feeding through orogastric or oroenteric tubes (OGT/OET) (Table 2).

The diagnosis of late-onset sepsis was bacteriological confirmation by means of positive blood cultures. Among the studied newborns, 14 newborns (47\%) had positive blood cultures. The most common microorganism was coagulase-negative staphylococci (Table 3).

\section{DISCUSSION}

Late-onset sepsis is a major cause of morbidity and mortality ${ }^{(5)}$. In this study there was no death in the sample during the hospitalization period in the NICU. However, 
Table 1 - Clinical and demographic characteristics of the preterm newborns. Porto Alegre, RS, 2013

\begin{tabular}{lc}
\multicolumn{1}{c}{ Baseline characteristics of the } \\
sample & $\mathbf{n = 3 0}$ \\
Sex (Female) & $22(73)$ \\
Twin & $8(27)$ \\
Type of labour (c-section) & $23(78)$ \\
Resuscitation manoeuvres & $20(67)$ \\
Weight/Gestational Age Ratio & \\
$\quad$ AGA & $15(50)$ \\
$\quad$ SGA & $15(50)$ \\
Birth weight & $1118.5 \pm 241.5^{*}$ \\
Apgar score & \\
$\quad 1^{\text {st }}$ minute & $5 \pm 2^{*}$ \\
$\quad 5^{\text {th }}$ minute & $7 \pm 1^{*}$ \\
Paediatric Gestational Age (weeks) & $28 \pm 2^{*}$ \\
Late-onset sepsis with positive & $14(47)$ \\
blood culture & \\
Hospitalized in the NICU (days) & $37(25-60)^{* *}$ \\
Days of life on discharge & $62 \pm 27^{*}$ \\
\hline
\end{tabular}

Source: Research data, 2014.

* Data expressed $n(\%) .{ }^{*}$ Average \pm standard deviation; ** Median and interquartile range. AGA: Appropriate for gestational age; SGA: Small for gestational age; NICU: Neonatal intensive care unit.

researchers ${ }^{(5)}$ found that the percentage of deaths among newborns who developed late-onset sepsis was 18\%, compared to $7 \%$ of the newborns that did not develop sepsis. The study also found a higher number of deaths among newborns with sepsis by gram-negative infection than by sepsis caused by fungi and gram-positive organisms ${ }^{(5)}$.

The present study showed a high incidence of diagnosed neonatal late-onset sepsis by gram-positive organisms verified through positive blood cultures. North-American authors ${ }^{(8)}$ showed that the risk of late-onset sepsis in newborns increases as gestational age decreases. The incidence of sepsis was 20\% in newborns with 28 weeks and $58 \%$ among newborns with a gestational age of 22 weeks ${ }^{(8)}$. However, another study ${ }^{(5)}$ that accompanied 6215 newborns showed a prevalence of $21 \%$ of late-onset sepsis among the newborns.

In relation to the risk factors for neonatal sepsis evaluated in this study, we found high rates of MV and CPAP. Corroborating this data, other researchers show that the use of MV is associated with a higher risk of late-onset sepsis ${ }^{(5,12)}$. A Brazilian study showed that newborns who developed sepsis were more exposed to invasive procedures, including the use of MV, PICC and surgical procedures, and $80 \%$
Table 2 - Distribution of technologies used with the newborns in relation to type and duration during hospitalization. Porto Alegre, RS, 2013

\begin{tabular}{lc}
\multicolumn{1}{c}{ Variables } & $\mathbf{n = 3 0}$ \\
Using MV (ETT)< 24 hours of life & $15(50)$ \\
Use of CPAP (nasal prong)< 24 & $14(74)$ \\
hours of life & $1(5)$ \\
Did not use MV or CPAP & $7(5-27)^{* *}$ \\
Days of MV & $5(2-11)^{* *}$ \\
Days of CPAP & $27(15-34)^{* *}$ \\
Total days of CVC & $4(1-7)^{* *}$ \\
Days of simultaneous CVC & $14(47)$ \\
Use of simultaneous CVC & $6(20)$ \\
$\quad$ PICC + umbilical arterial catheter & $2(6.7)$ \\
PICC + umbilical venous catheter & $5(17)$ \\
PICC + UAC + UVC & $1(3.3)$ \\
UAC + UVC & $16(53)$ \\
PICC only & $28(93.3)$ \\
Use of TPN (patients) & $15(9.5-22.2)^{* *}$ \\
Days of NPT & $3(1.0-5.5)^{* *}$ \\
NPO time (days) & $40(25-48)^{* *}$ \\
Use of OGT/OET (days)
\end{tabular}

Source: Research data, 2014.

* Data expressed $n(\%) .{ }^{*}$ Average \pm standard deviation; ${ }^{* *}$ Median and interquartile range. MV: Mechanical Ventilation; ETT: Endotracheal Tube; CPAP: Continuous positive airway pressure; CVC: Central venous catheter; PICC: Peripherally inserted central catheter; UAC: umbilical arterial catheter; UVC: umbilical venous catheter; TPN: Total parenteral nutrition; NPO: Nothing by mouth; OGT: orogastric tube; OET: oroenteric tube.

Table 3 - Types of micro-organisms identified in newborns with confirmed late-onset sepsis. Porto Alegre, RS, 2013

\section{Micro-organisms}

$n=14$

Gram-positive organisms

Coagulase-negative S. $12(86)$

Coagulase-negative S. and Enterococcus sp. 1 (7)

Fungus

Candida Parapsilosis

$1(7)$

Source: Research data, 2014

Data expressed in $n$ (\%). S.: Sthaphilococcus

of the newborns with diagnosed sepsis underwent MV $(p<0.001)^{(12)}$. In this study, the median duration of MV was 7 (5 - 27) days. The risk of late-onset sepsis increases as the number of MV days increases ${ }^{(5)}$. A multicentre research trial in North America ${ }^{(5)}$ showed that $50 \%$ of the newborns that underwent MV for 28 days or more developed late-onset 
sepsis, while only $9 \%$ of newborns that underwent MV for 7 days or more developed late-onset sepsis. The same study ${ }^{(5)}$ also showed that newborns who developed late-onset sepsis underwent MV for longer that the newborns who did not develop sepsis.

Only CPAP was used for most of the sample during the first 24 hours of life. A study conducted in Norway ${ }^{(14)}$ showed that sepsis was more frequent among the newborns who used CPAP in the first 24 hours than among the newborns who underwent MV for the same period. The reason for this association, according to the authors ${ }^{(14)}$ is nosocomial, since after the third day of age, the upper airways of newborns are colonized by coagulase-negative S. and S. Aureus, while the lower airways of intubated newborns are considered sterile. The intense flow of gases, the manipulation of prongs and nasopharyngeal aspiration damage the immature mucous membranes and break the defence barriers, which paves the way for nosocomial bacterial infection. This would explain the association and suggests that institutions and professionals should remain alert to these risk factors ${ }^{(14)}$.

Most of the sample used CVC for many days, which several studies consider the key risk factor for neonatal sepsis. A Brazilian trial(12) that assessed the risk factors for late-onset sepsis found that there were more cases of infection among the newborns who were submitted to PICC for more than 11 days (76.2\%) than among the newborns who were not submitted to PICC $(23.8 \%)(p<0.0001)$. Consequently, CVC in that study was considered a significant predictor for late-onset neonatal sepsis, since the prevalence of late-onset neonatal sepsis was 397\% greater among the newborns that received a PICC for 11 days or more ${ }^{(12)}$.

A large part of the sample of this study used TPN for several days, and the time that the newborns remained in NPO also put them at greater risk of acquiring infections. Researchers ${ }^{(5)}$ found that there were more cases of late-onset sepsis among newborns subjected to TPN and that the risk increases as the number of days of TPN via CVC increases. A study ${ }^{(15)}$ carried out in Canada that aimed to examine the association between early enteral nutrition and late-onset sepsis by coagulase-negative $\mathrm{S}$. found that the newborns with very low birth weight who received enteral nutrition before 24 hours of age remained less days in TPN. Probably on account of the reduced number of days of NPT and the reduced risks associated with the need to use catheters, the number of cases of late-onset sepsis by coagulase-negative $\mathrm{S}$. was significantly lower in newborns who received early enteral nutrition ${ }^{(15)}$. Other studies also demonstrate the benefits of early enteral nutrition on intestinal microbiota and the reduced use of TPN ${ }^{(16)}$.
This study revealed a high percentage of newborns with positive blood culture, especially for the microorganism coagulase-negative S.. Other authors reported coagulase-negative $\mathrm{S}$. as the most frequent microorganism ${ }^{(5,17-18)}$. A study ${ }^{(18)}$ conducted in Taiwan found a high prevalence of neonatal sepsis caused by coagulase-negative S., although the mortality associated with sepsis by coagulase-negative S. was $2.4 \%$.

It should be noted that coagulase-negative $S$. is not associated with more serious infections and higher mortality, but it is considered one of the most resistant microorganisms to the antibiotics that are routinely used in the NICU (17). In this study, there was a case of infection by Candida parapsilosis. This fungus is considered rare, but similar studies have shown that it has a high mortality rate ${ }^{(18-19)}$.

Most nosocomial infections acquired in the NICU are the result of procedures to preserve the life of these newborns, so it is difficult to reduce the infection rate by mereIy limiting the number of procedures. In addition, it is not acceptable to consider these infections as a consequence of neonatal intensive care. It is therefore the responsibility of the healthcare team to minimize the risks of infection and to safely perform invasive procedures when necessary. Prevention strategies of adult and paediatric ICU may be equally effective in the NICU(11). Strategies to reduce late-onset sepsis must be implemented and constantly reviewed to reduce colonization ${ }^{(12,20)}$. Changes in routines can have a major impact on reducing the rates of neonatal infection and preventing morbidity and mortality ${ }^{(20)}$.

The limitations of this study are related to the study population. The newborns weighing less than 1500 grams admitted to the NICU comprise a group with a low number of births and a low survival rate, which can impair inclusion and follow-up of these patients.

\section{口CONCLUSIONS}

The incidence of late-onset neonatal sepsis in newborns weighing less than $1500 \mathrm{~g}$ is a constant concern of nurses care due to the vulnerability of preterm infants and the intensive need of technology. In addition, the immunological immaturity of this population and the invasive procedures performed in the NICU are risk factors for the development of late-onset sepsis. Greater knowledge of the profile of newborns in the NICU and the risk factors to which they are exposed are fundamental for the planning of nursing care for these patients.

Nursing plays a relevant role in the care of preterm infants in the NICU, so nurses must be attentive to these risk factors in order to prevent infection and promote individualized care for newborns. 
Future research is needed on the Brazilian population of preterm newborns weighing less than 1500 grams to address the risk factors (ventilation, venous catheters, enteral and parenteral nutrition) associated with late-onset neonatal sepsis and consequently develop and test strategies that help prevent nosocomial infections.

\section{REFERENCES}

1. Medlock S, Ravelli ACJ, Tamminga P. et al. Prediction of mortality in very premature infants: a systematic review of prediction models. Plos One. 2011 [citado in 2014 jul. 07];6(9):e23441. Available at: http://www.plosone.org/article/ fetch0bject.action?uri=info:doi/10.1371/journal.pone.0023441\&representation $=P D F$

2. Howson ECP, Kinney MV, Lawn JE, editors. Born too soon: the global action report on preterm birth. Geneva: WHO, 2012 [citado in 2014 jul. 08]. Available at: <http://www.savethechildren.ca/document.doc?id=194>

3. Agência Nacional de Vigilância Sanitária (BR), Gerência de Vigilância e Monitoramento em Serviços de Saúde, Gerência Geral de Tecnologia em Serviços de Saúde. Critérios nacionais de infecções relacionadas à assistência à saúde: neonatologia. Brasília; 2013.

4. Ministério da Saúde (BR), Secretaria de Atenção à Saúde, Departamento de Ações Programáticas e Estratégicas. Atenção à saúde do recém-nascido: guia para os profissionais de saúde: intervenções comuns, icterícia e infecções. Brasília; 2011. v. 2

5. Stoll BJ, Hansen N, Fanaroff AA, Wright $L L$, Carlo WA, Ehrenkranz RA, et al. Late-onset sepsis in very low birth weight neonates: the experience of the NICHD Neonatal Reseach Network. Pediatrics. 2002 Aug;110(2 Pt 1):285-91.

6. Levy, MM, Fink, MP, Marshall JC, Abraham E, Angus D, Cook D, et al. 2001 SCCM/ ESICM/ACCP/ATS/SIS International Sepsis Definitions Conference. Intensive Care Med. 2003;29(4):530-8.

7. Camacho-Gonzalez A, Spearman PW, Stoll BJ. Neonatal infectious diseases: evaluation of neonatal sepsis. Pediatr Clin North Am. 2013;60(2):367-89.

8. Stoll BJ, Hansen NI, Bell EF, Shankaran S, Laptook AR, Walsh MC, et al. Neonatal outcomes of extremely preterm infants from the NICHD Neonatal Research Network. Pediatrics. 2010 Sep;126(3):443-56.

\section{Author's address:}

Maria Luzia Chollopetz da Cunha

Escola de Enfermagem, Universidade Federal do Rio Grande do Sul

Rua São Manoel, 963, Rio Branco

90620-110 Porto Alegre - RS

E-mail: maria.luzia@ufrgs.br
9. Meireles LA, Vieira AA, Costa CR. Avaliação do diagnóstico da sepse neonatal: uso de parâmetros laboratoriais e clínicos como fatores diagnósticos. Rev Esc Enferm USP. 2011;45(1):33-9.

10. Hentges CR, Silveira RC, Procianoy RS, Carvalho CG, Filipouski GR, Fuentefria RN, et al. Association of late-onset neonatal sepsis with late neurodevelopment in the first two years of life of preterm infants with very low birth weight. J Pediatr (Rio J). 2014;90(1):50-7.

11. Polin RA, Denson S, Brady M T, et al. Strategies for prevention of health care-associated Infections in the NICU. Pediatrics. 2012;129(4):e1085-93, 2012.

12. Freitas BAC, Peloso M, Manella LD, Franceschini SCC, Longo GZ, Gomes AP, et al. Sepse tardia em pré-termos de uma unidade de terapia intensiva neonatal: análise de três anos. Rev Bras Ter Intensiva. 2012;24(1):78-85.

13. Silva, SMR. Características dos recém-nascidos pré-termo com peso inferior a $1.500 \mathrm{~g}$ e sepse neonatal tardia [dissertação]. Porto Alegre (RS): Universidade Federal do Rio Grande do Sul; 2014.

14. Rønnestad A, Abrahamsen TG, Medbø S, Reigstad H, Lossius K, Kaaresen PI, et al. Septicemia in the first week of life in a Norwegian national cohort of extremely premature infants. Pediatrics. 2005 Mar;115(3):e262-8.

15. Lavoie PM. Earlier initiation of enteral nutrition is associated with lower risk of late-onset bacteremia only in most mature very low birth weight infants. J Perinatol. 2009 Jun;29(6):448-54.

16. Morgan J, Bombell S, McGuire W. Early trophic feeding versus enteral fasting for very preterm or very low birth weight infants. Cochrane Database of Syst Rev. 2013 Mar 28;3:CD000504. doi: 10.1002/14651858.CD000504.pub4.

17. Ozkan H, Cetinkaya M, Koksal N, Celebi S, Hacimustafaoglu M. Culture-proven neonatal sepsis in preterm infants in a neonatal intensive care unit over a 7 year period: coagulase-negative Staphylococcus as the predominant pathogen. Pediatr Int. 2014 Feb;56(1):60-6.

18. Lim WH, Lien R, Huang YC, Chiang MC, Fu RH, Chu SM, et al. Prevalence and pathogen distribution of neonatal sepsis among very-low-birth-weight infants. Pediatr Neonatol. 2012 Aug;53(4):228-34.

19. Romanelli, R. M, Anchieta LM, Mourão MVA, Campos FA, Loyola FC, Armond $G A$, et al. Risk factors and lethality of laboratory-confirmed bloodstream infection caused by non-skin contaminant pathogens in neonates. J Pediatr (Rio J.). 2013;89(2):189-96

20. Shane AL, Stoll BJ. Neonatal sepsis: progress towards improved outcomes. J Infection. 2014 Out;68 Suppl 1:S24-32.

Received: 14.10.2014

Approved: 24.09.2015 